\title{
Implementation of Moodle LMS in Learning Islamic Education in Elementary Schools during the COVID-19 Pandemic
}

\author{
Nadia Risya Faridah ${ }^{1}$, Syafi'i' ${ }^{2}$ \\ nadiarisya37@gmail.com 1
}

\begin{abstract}
The ongoing COVID-19 pandemic has made education world always innovate in the learning process. Various applications and online learning strategies have become a new culture for educators and students. For this reason, this study aims to analyze the implementation, advantages, and disadvantages of the Moodle LMS in learning Islamic education at the elementary school level during the COVID-19 pandemic. This study used a qualitative-descriptive approach. Utilizing interview and observation data collection techniques, this study's results revealed that the learning process of Islamic education was divided into three stages. The initial stage was the activity of opening by the teacher to students. Followed by the core stage, students carried out instructions by the teacher to access the Moodle according to the agreed time period. The last stage was the closing stage, where the teacher and students returned face to face to evaluate and pray together. Meanwhile, the advantages of Moodle LMS in learning covered a free and easy to use platform and supported several document types for the learning process. However, the disadvantages consisted of some foreign features for students, and the access times were slow if the owned bandwidth was not qualified.
\end{abstract}

Keywords: Moodle, Learning, Islamic education

Abstrak: $\quad$ Pandemi Covid-19 yang belum usai menjadikan dunia pendidikan selalu berinovasi dalam proses pembelajaran. Berbagai aplikasi dan juga strategi pembelajaran secara online menjadi kultur baru bagi pendidik dan peserta didik. Penelitian ini bertujuan untuk menganalisis implementasi, kelebihan dan kelemahan LMS Moodle dalam pembelajaran Pendidikan Agama Islam pada jenjang sekolah dasar pada masa pandemi Covid-19. Penelitian ini menggunakan pendekatan kualitatifdeskriptif. Dengan teknik pengumpulan data dengan wawancara dan observasi, hasil pada penelitian ini adalah dalam proses pembelajaran PAI terbagi menjadi tiga tahap yakni tahap awal sebagai kegiatan pembukaan guru terhadap peserta didik. Dilanjutkan tahap inti, peserta didik melakasanakan instruksi oleh guru untuk mengakses moodle sesuai dengan jangka waktu yang telah disepakati. Dan yang terakhir adalah tahap penutup, dimana guru dan peserta didik kembali tatap muka untuk melakukan evaluasi dan doa bersama. Adapun kelebihan LMS Moodle dalam pembelajaran yakni platform yang gratis, mudah digunakan, mendukung beberapa tipe dokumen yang menunjang proses pembelajaran. Kekurangannya adalah terdapat fitur asing bagi peserta didik dan lambannya waktu akses jika bandwidth yang dimiliki kurang mumpuni.

Kata Kunci: $\quad$ Moodle, Pembelajaran, PAl

\begin{tabular}{llll}
\hline Submitted: July 2021 & Reviewed: August $2021 \quad$ Accepted: August 2021 & Published: September 2021
\end{tabular}


C oronavirus disease (COVID-19) is spreading in various parts of the world, one of which is in Indonesia. It greatly affects the joints of social life. Many government efforts have been made to reduce the level of people exposed to the virus. Policy after policy was launched to facilitate people's lives. One of the things seen was when the Ministry of National Education and Culture issued Circular Letter No. 4 on the Implementation of Educational Policies in the Emergency Period for the Spread of Coronavirus Disease (COVID-19). Hence, the world of education has now evolved, which was originally the learning process carried out in the classroom to online or distance learning. Distance learning is one of the options chosen to provide learning to students without gathering and in groups (Simanjuntak \& Kismartini, 2020).

Distance learning can be overcome with technological developments and advances in the digital era. Information and telecommunications technology that has coexisted with students and educational institutions will eliminate the limitations of space and time in the world of education. Some things that can happen include 1) students can easily access learning materials that have been prepared by teachers anywhere without being limited by space and time. (2) Students can easily learn and discuss with experts in the field of interest. In addition, (3) learning materials can be easily taken in various parts of the world without depending on where the students study.

In carrying out distance learning, students cannot be separated from the use of electronic devices, such as mobile phones, tablets, laptops, and internet connections, which are utilized to support the learning process (Firyal, 2020). Thus, distance learning is still not without advantages and disadvantages in the implementation process. The advantages of distance learning are that learning becomes more effective and efficient, students become free to study learning materials, expands the range of learning, and encourages students to be independent (Lindawati, 2019). Asides from the advantages, the disadvantages are that students are not active during learning, do not express their aspirations and opinions, and learning becomes boring (Kutsiyyah, 2021). It happens at the higher education to elementary level, as seen in MI Miftahul Huda Ngreco. It was revealed that in its online learning, there were several obstacles, including students having difficulty understanding the material presented, and in completing daily assignments and tests, students were assisted by their parents and caregivers (Rahmawati et al., 2020). Therefore, innovative distance learning tools are needed to provide alternative learning, flexible, rich in opportunities, and in accordance with the current needs of students.

To meet the learning needs of students, it is possible to use e-learning as a support so that the education system in Indonesia continues to run as it should. Meanwhile, what needs to be considered in implementing e-learning are 1) preparing material in accordance with learning indicators, 2) using learning methods according to the students' characteristics to facilitate learning, 3) collaborating text and images so that the display is more attractive and easy to read, 4 ) learning can be accessed directly with teachers or individuals, 5) preparing other learning resources related to the material, and 6 ) building shared insights about their use so that later learning objectives can be achieved (Savira \& Suharsono, 2020). One of the e-learning that can be used as an appropriate learning media is Moodle (Modular Object-Oriented Dynamic Learning Environment). Moodle is intended as a dynamic learning place using an object-oriented model or is a dynamic web-based educational environment package (Joyo Sampurno et al., 2015).

Moodle is an open-source Learning Management System (LMS), where users can modify it based on their desired learning needs for free. Within it, several sections can be used to include materials, discussions, assignments, and quizzes. In addition, class participants are students who have 
been registered and given access rights by entering their username and password. In this case, teachers can also set access times for their students. That way, students can access all activities on the course based on meetings. Students can also use the chat menu to communicate with teachers and other students. Moreover, the features offered in Moodle are 1) course content management, 2) synchronous and asynchronous communication, 3) the uploading of content, 4) the return of students work, 5) peer assessment, 6) student administration, 7) the collection and organization of students grades, 8) online questionnaires, 9) online quizzes, and 10) tracking tools (Syamsudin et al., 2014).

Moodle-based e-learning has been used by several educational institutions to meet learning needs during the COVID-19 pandemic. Moodle is designed to have many features that can be used and adapted to the needs. The process of internet-based activities through websites and mobiles is specifically built with the principles of social constructionist pedagogy to assist teachers in the process of teaching and learning activities (Dhika et al., 2020). It can be seen in the research conducted by Budiharti, which resulted in the use of Moodle to improve students' cognitive abilities at the junior high school level in natural science subjects, with the percentage of completeness in the first cycle reaching $50.69 \%$ and the second cycle reaching $77.8 \%$ (Budiharti et al., 2015). Not only that, in her experimental research, Nur'aini also found that students in the senior high school level became more active in using Moodle for learning than classes that used other platforms/media (Ulyatin, 2019). However, in its implementation, there were also supporting and inhibiting factors, such as at SDIT Lukman Al Hakim. At that school, the supporting factor is that schools provided paid service facilities so that the learning process did not experience capacity limitations, different from unpaid services, while the inhibiting factor is that some students still experienced difficulties in online learning due to unstable networks (Lukman et al., 2020).

Based on the explanation above, the use of Moodle was also chosen by SDIT At-Taqwa Surabaya to facilitate the learning process, especially in Islamic education subjects so that students did not get bored with their learning activities. With this platform, all forms of supporting the learning process, ranging from materials, exercises, assessments, and teacher interactions with students, were collected in the Moodle Learning Management System. For this reason, with this study, the researchers are interested in exploring how to implement Moodle if used by students at the elementary education level, accompanied by advantages and disadvantages in its use.

\section{RESEARCH METHODS}

This study used a qualitative approach with the type of field research. This type of research field research is a study whose data are taken and carried out in the field, such as the community environment, institutions, and community organizations, by analyzing and presenting factual data systematically about the state of the research object (Moleong, 2008). It aligns with the definition of qualitative research, which is a study that produces descriptive data output in the form of written or spoken words from people and observable behavior.

This research was conducted at SDIT At-Taqwa Surabaya. The reason for choosing the location was that one of the researchers had a friend as a teacher of Islamic education subjects at SDIT AtTaqwa Surabaya school, making it easier for researchers in terms of data collection. The data obtained in this research implementation were sourced from the subject, research informants, and literature as supporting scientific theories. The subjects selected in this study were sixth grade Islamic education teachers at SDIT At-Taqwa Surabaya. Meanwhile, informants in the study who could provide related information consisted of level six coordinators, sixth grade teachers, and students. 
In addition, the instruments used in the study were observation and interviews. Observations were made to obtain information related to the learning process implementation using Moodle. This observation activity was intended to directly pay attention to the use of Moodle by teachers in the learning process implementation at SDIT At-Taqwa Surabaya to find data and information directly and naturally from the ongoing activities. The learning process observed by the researchers included the introduction, the core of learning, and how the teacher closed online learning. Meanwhile, interviews were conducted to obtain data regarding what Moodle features were utilized to support learning, the Moodle implementation carried out by teachers starting from pre to post learning, and the strengths and weaknesses felt by teachers and students in the teaching and learning process using Moodle.

In this study, the data were in the form of words, writings, and behaviors carried out by teachers and students related to the use of Moodle in learning Islamic education at SDIT At-Taqwa Surabaya. The data that had been collected were then analyzed employing the analytical technique developed by Miles and Hubberman.

\section{RESULTS AND DISCUSSION}

In the face of the COVID-19 pandemic, several government regulations have been issued to prevent the virus spread from getting higher. The current effort is social distancing. Social distancing is an act of maintaining social distance, such as avoiding crowds and physical contact. The existence of these efforts has clearly affected the education sector. Face-to-face learning has changed to online learning (on the network), which has also been echoed by the Ministry of Education and Culture by issuing Circular Letter No. 4 of 2020 concerning the Implementation of Education Policies in the Emergency Period for the Spread of Coronavirus Disease (COVID-19). With this policy, a solution is needed in the world of education in the face of a condition that was never imagined before. Various efforts were carried out to maximize the activities of the learning process, which became a challenge for educational institutions in packaging it. In carrying out this online learning, educators must be able to adapt to the facilities and infrastructure used and the needs of students. As stated by Ika Handarini \& Sri Wulandari (2018), teachers must be able to develop the teaching profession, carry out their duties by adjusting to the needs of students, and package learning materials according to the times. Therefore, as teachers of Islamic education subjects, they also need to innovate the learning process so that it is not monotonous by only listening to lectures, watching videos, or relying on handbooks to do assignments, but also can use quizzes, interactive materials, and vary the learning model used.

In line with that, SDIT At-Taqwa used Moodle as a support for the learning process during the COVID-19 pandemic so that students did not feel bored and could be enthusiastic about online learning. Moodle is an open-source program that can convert a learning medium into a web form and function as a medium of information. Media accessed by students can be in the form of text, graphics, videos, animations, practice questions, and direct feedback. Students can also access it anywhere and anytime as long as they are connected to the internet network. Moodle can accommodate various learning material formats, such as word, ppt, pdf, and swf. In addition, teachers can also include material in the form of links as additional learning references for students. This platform allows for the exchange of information between geographically dispersed users through synchronous (chat) and asynchronous communication (discussion forums) mechanisms (Lukman et al., 2020). 
In implementing Moodle in the learning process used by SDIT At-Taqwa Surabaya, it could be accessed through the website kelasonline.sekolahattaqwa.sch.id. Meanwhile, the initial display when students entered the page is as follows.

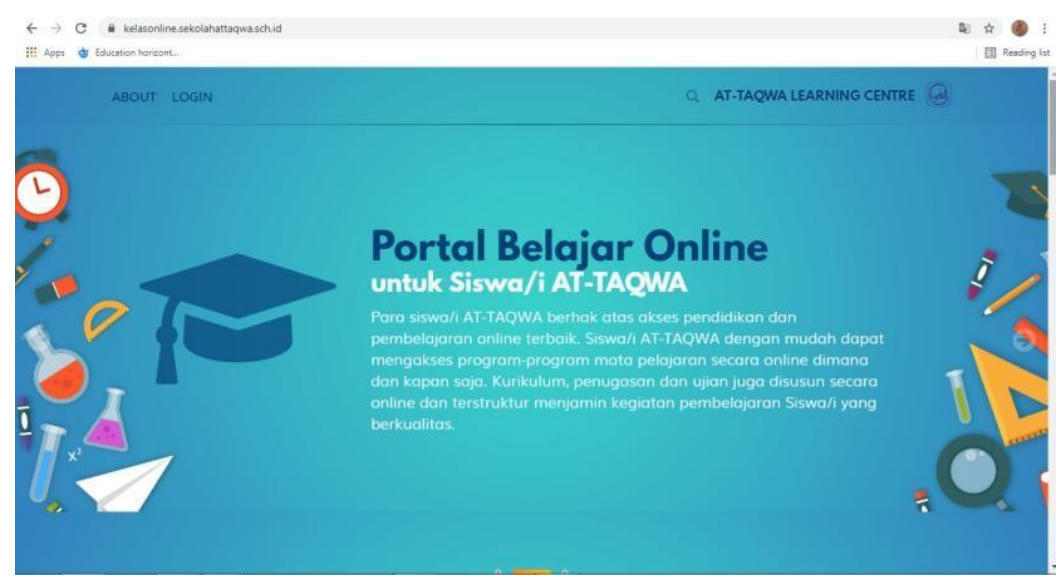

Figure 1. Initial display of Moodle at SDIT At-Taqwa Surabaya

After the page (Figure 1) was opened, students were asked to log in by entering the username and password provided by the operator. After entering the intended subject course, students checked the Zoom Meeting ID, which was used face-to-face for the online learning process. The learning process was carried out according to the schedule prepared by the school. For Islamic education learning, one meeting was scheduled a week, with an allocation of 45 minutes.

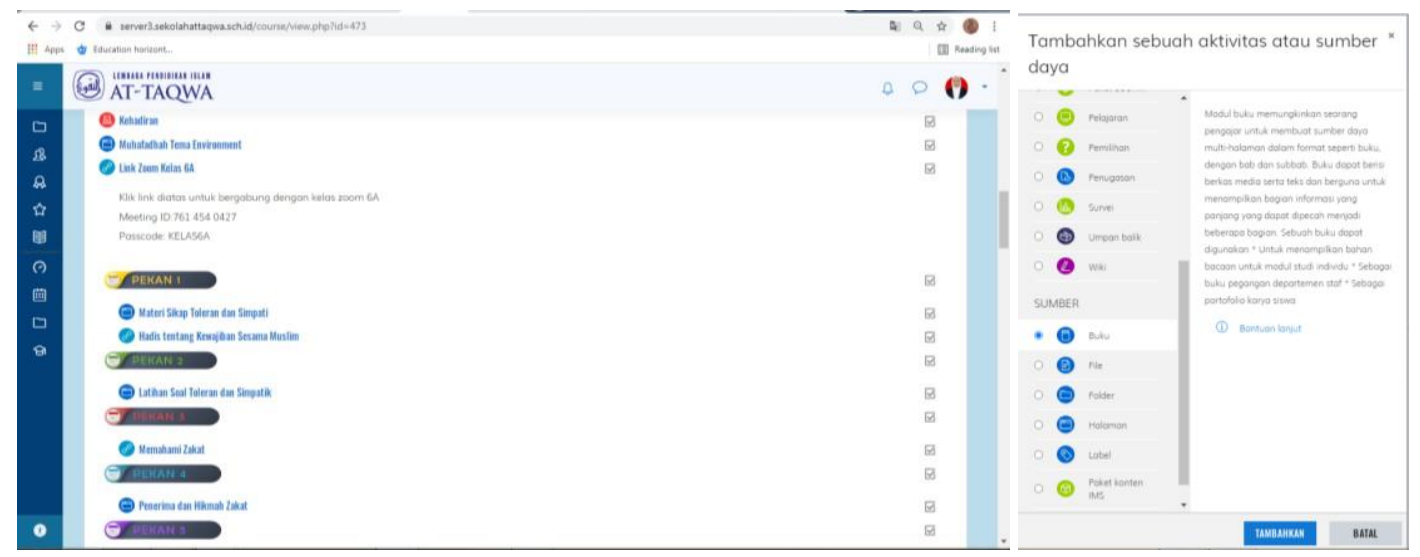

Figure 2. Display of Islamic education courses on Moodle

Before the lesson was carried out, the teacher prepared the material, uploaded on the course page for Islamic education subjects (Figure 2), by activating the edit mode feature in the course settings and then adding any materials and activities used in learning. Materials and activities could be adapted to the planned learning objectives, which could be material in the form of ppt, url, video, or others. After that, it was continued with the learning process, divided into three stages: opening, core, and closing. 
In the opening stage, teachers and students held online face-to-face meetings at Zoom Meetings with IDs distributed in Islamic education courses. The teacher opened the lesson by reading pledges, prayers, dhikr, and continued by checking the hadith memorization while waiting for students who were not present. Then, when all the students were present, the teacher continued to check their attendance and readiness to take part in learning. After the students had focused, the teacher conveyed the learning objectives and instructed the student activities in learning Islamic education at the meeting. Before moving on to the core stage, Islamic education teachers usually played a short video related to the material to be taught as a stimulus to move on to the next activity. At the core stage, the Zoom Meeting was temporarily terminated or with an agreed period of time between the teacher and students. Students were directed again to the Moodle platform to access Islamic education materials uploaded by the teacher before learning took place. The material presented was interactive ppt, quiz links (quizziz, kahoot, wordwall, etc.), and practice questions as a form of assessment in learning. If they had difficulty, students could use the chat feature available on the Moodle platform. After the students carried out the teacher's instructions according to the specified time, it was continued to the third stage, namely closing. At this stage, students returned to the same Zoom Meeting to ask again about the obstacles they faced, evaluate together the learning of Islamic education, and continue praying together as a sign that the learning was over.

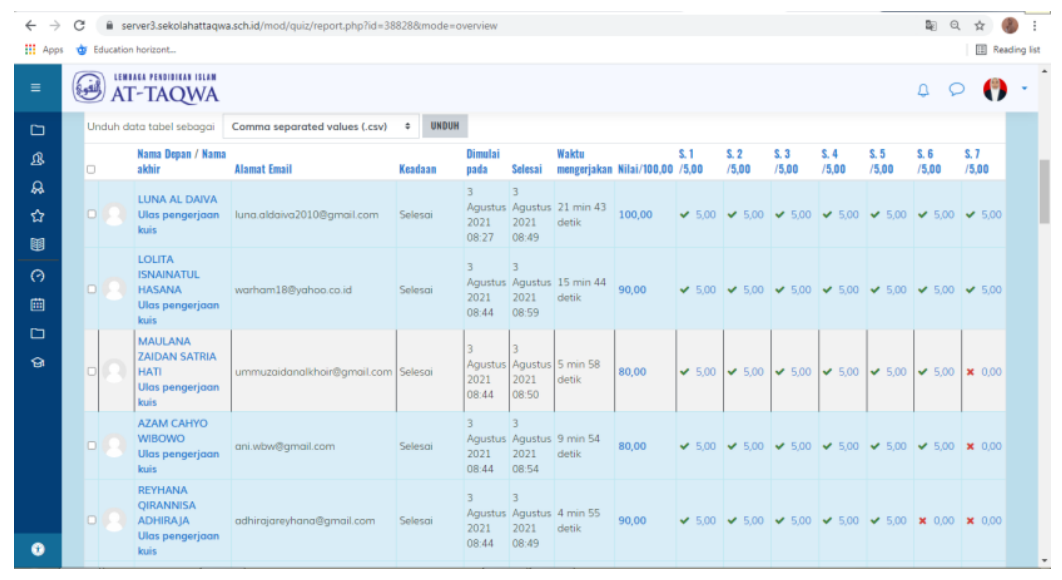

Figure 3. The display of the quiz feature assessment on Moodle

After the learning process had been carried out, the teacher continued to check the assessment results (Figure 3) of basic competencies done by students, as a form of evaluation and reflection for the implementation of further learning activities.

\section{Advantages and Disadvantages of Using Moodle}

The use of Moodle in more effective learning does not escape the accompanying advantages and disadvantages. The advantage is that every educational institution can download Moodle software for free via https://moodle.org/, suitable for all levels of education and for all learning materials, easy to use and can be adapted to the needs of teachers and students, supports several document types to support the learning process, and have quiz facilities, assignments, and scoring that can be arranged by the teacher. Not only that, the features available on Moodle are more varied in supporting online learning activities compared to other platforms. It corroborates with Faridzatun 
Nadziroh's research, stating that Moodle has more complete features than Edmodo and Google Classroom (Nadziroh, 2017). By looking at the advantages possessed by the Moodle LMS, it makes students' learning motivation increase, more active, independent in learning, and on time in completing assignments.

Meanwhile, the disadvantages of using Moodle is that some features confused students, and access time became slow when the bandwidth was not sufficient. As stated by (Nurkhalik et al., 2014), the slow access time is due to the small bandwidth and poor design of materials with large capacity files. Therefore, the solution implemented was for schools to hold training for teachers and students to operate the Moodle LMS so that the learning process could be carried out optimally. To deal with the slow access time, the school also added an additional server so that if used by all levels, there was no difficulty in accessing it. The solution used is also in line with the suggestions given by Sakroni and Siswanto, in their research: 1) the implementation of learning using information technology-based applications is needed in the new normal era, 2) periodic training for teachers to improve competence in implementing online learning, and 3) the need for infrastructure support for teachers and students in using learning and assessment through online applications (Sakroni \& Siswanto, 2021).

\section{CONCLUSIONS AND RECOMMENDATIONS}

The implementation of Moodle in the learning process of Islamic education at SDIT At-Taqwa Surabaya was divided into three stages. The initial stage was the activity of opening by the teacher to students. Followed by the core stage, students carried out instructions by the teacher to access the Moodle according to the agreed time period. The last stage was the closing stage, where the teacher and students returned face to face to evaluate and pray together. Meanwhile, the advantages of Moodle LMS in learning covered a free and easy to use platform and supported several document types for the learning process. However, the disadvantages consisted of some foreign features for students, and the access times were slow if the owned bandwidth was not qualified. However, learning using the Moodle LMS still requires solutions and suggestions for improvement to increase student motivation and learning outcomes optimally. In addition, this research can be used by other educational institutions to facilitate the learning process during the ongoing COVID-19 pandemic.

\section{REFERENCES}

Budiharti, R., Ekawati, E. Y., Wahyuningsih, D., \& H, F. F. (2015). Penggunaan Blended Learning dengan Media Moodle untuk Meningkatkan Kemampuan Kognitif Siswa SMP. Jurnal Cakrawala Pendidikan, 1(1), 140-148. https://doi.org/10.21831/cp.v1i1.4184

Dhika, H., Destiawati, F., Surajiyo, S., \& Jaya, M. (2020). Implementasi Learning Management System Dalam Media Pembelajaran Menggunakan Moodle. Prosiding Seminar Nasional Riset Information Science (SENARIS), 2(0), 228-234. http://tunasbangsa.ac.id/seminar/index.php/senaris/article/view/166 
Firyal, R. A. (2020). Pembelajaran daring dan kebijakan new normal pemerintah. LawArXiv Papers, 17. https://osf.io/preprints/lawarxiv/yt6qs/

Ika Handarini, O., \& Sri Wulandari, S. (2018). Pembelajaran Daring Sebagai Upaya Study From Home (SFH) Selama Pandemi Covid 19. Family Practice, 35(5), 639-643. https://doi.org/10.1093/fampra/cmy005

Joyo Sampurno, P., Maulidiyah, R., \& Zuliana Puspitaningrum, H. (2015). Implementasi Kurikulum 2013: MOODLE (Modular Object Oriented Dynamic Learning Environment) dalam Pembelajaran Fisika melalui Lembar Kerja Siswa pada Materi Optik di SMA (Halaman 54 s.d. 58). Jurnal Fisika Indonesia, 19(56), 54-58. https://doi.org/10.22146/jfi.24361

Kutsiyyah. (2021). Analisis fenomena pembelajaran daring pada masa pandemi (harapan menuju blended learning). Edukatif : Jurnal IImu Pendidikan, 3(4), 1460-1469.

Lindawati, Y. I. dan C. A. R. (2019). Adaptasi Guru Dalam Implementasi Pembelajaran Daring Di Era Pandemi Covid-19. Prosiding Seminar Nasional Pendidikan FKIP, 3(2252), 58-66. http://www.tiyybjb.ac.cn/CN/article/downloadArticleFile.do?attachType=PDF\&id=9987

Lukman, I. T., Hakim, A., \& Yogyakarta, S. (2020). Implementasi pembelajaran fully online e-learning berbasis moodle Implementation of Fully Online E-Learning Based on Moodle in Class 2 SD IT Lukman Al Hakim Sleman Yogyakarta. 3(2), 78-89.

Moleong, Lexy J. Metode Penelitian Kualitatif, Bandung: Remaja Rosdakarya, 2008

Nadziroh, Faridzatun. (2017). Analisa Efektifitas Sistem Pembelajaran. 2(1), 1-14.

Nurkhalik, R. D., Syaichudin, M., Pendidikan, T., \& Pendidikan, F. I. (2014). lebih besar dari t. Rahmawati, N. R., Rosida, F. E., \& Kholidin, F. I. (2020). Analisis Pembelajaran Daring Saat Pandemi Di Madrasah Ibtidaiyah. SITTAH: Journal of Primary Education, 1(2), 139-148. https://doi.org/10.30762/sittah.v1i2.2487

Savira, F., \& Suharsono, Y. (2020). Implementasi E-Learning Berbasis Moodle Di Masa Pandemi Covid 19. Journal of Chemical Information and Modeling, 01(01), 1689-1699.

Simanjuntak, S. Y., \& Kismartini. (2020). Respon Pendidikan Dasar Terhadap Kebijakan Pembelajaran Jarak Jauh Selama Pandemi Covid-19 di Jawa Tengah. Jurnal IImiah Wahana Pendidikan, 6(3), 308-316. https://doi.org/10.5281/zenodo.3960169

Sakroni, \& Siswanto. (2021). Using Microsoft Quiz and Mobile Exam Applications to Improve Teacher Competence in Online Learning in the New Normal Era. Teknodika, 19(01), 59-70.

Syamsuddin, I., \& min, A. (2014). Assessing Moodle as Learning Management System Platform for English Course Based TOEFL. International Journal of Computer Trends and Technology, 18(6), 276-279. https://doi.org/10.14445/22312803/ijctt-v18p158

Ulyatin, N. A. (2019). Pengembangan Media Pembelajaran PAI berbasis Moodle Efektif terhadap Keaktifan Siswa Kelas X SMA Negeri 1 Blora.

How to cite: Faridah, N. R., \& Syafi'i. (2021). Implementation of Moodle LMS in Learning Islamic Education in Elementary Schools during the COVID-19 Pandemic. Teknodika, 19 (2), 136-143. DOI: https://doi.org/10.20961/teknodika.v19i2.53071 